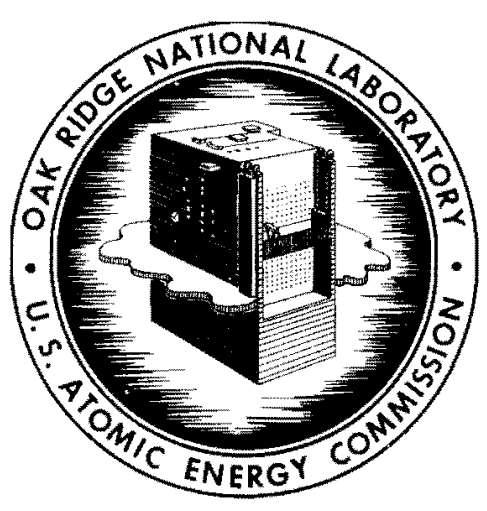

OAK RIDGE NATIONAL LABORATORY

operated by

UNION CARBIDE CORPORATION

for the

U.S. ATOMIC ENERGY COMMISSION

ORNL - TM- 354

COPYNO. - 4

DATE - September 17, 1962

\title{
USE OF THE DRY MAINTENANCE FACILITY \\ FOR HRT MAINTENANCE
}

J. Paul Jarvis

\begin{abstract}
A portable shield, described in ORNL CF 60-10-85, was utilized in performing nine semi-direct dry maintenance jobs on the HRT. The shield proved to be completely reliable, affording a considerable savings in maintenance costs and reactor downtime.
\end{abstract}

\section{NOTICE}

This document contains information of a preliminary nature and was prepared primarily for internal use at the Oak Ridge Notional Laboratory. It is subiect to revision or correction and therefore does not represent a final report. The information is not to be abstracted, reprinted or otherwise given public dis. semination without the approval of the ORNL patent branch, Legal and Information Control Department. 
This report wos prepored as an account of Goveenment sponsored work. Neither the United Stotes, nor the Commission, nor any person octing on beholl of the Commission:

A. Makes any warrenty or repesentotion, expressed or implied, with reapect to the oceurocy, completuness, of usefulness of the information contained in this report, or that the use of any information, opparotus, method, or process disclosed in this report may not infring prirataly awned rights; or

B. Assumes any liabilitios with texpet to the use of, of for danogex rexulting from the uxe of ony information, opporatus, mothod, or process diselosed in this report.

As used in the above, "person octing on beholf of the Commission" includes ony employes or

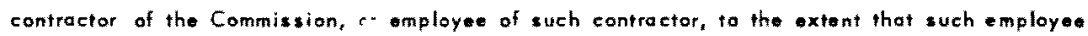
or Eantractor of the Commission, or employee of such contractor prepares, disseminetes, or provides access to, any information pursuant to his omplayment a contract with the Cammission, of his amplayment with such contraetor. 


\section{INIRODUCTION AND HISTORY}

Fabrication of the dry maintenance shield* was completed in the ORNL shops early in September, 1960. The shield was assembled at the fabrication shop and operational checks were performed. A few minor modifications were made to the shield under the direction of P. P. Holz. The shield was delivered to the 7500 area the same month.

Early in October, 1960, the shield was assembled and tested in conjunction with a program to familiarize and train personnel in the use of the shield. Detailed job procedures were written covering the use of the shield in performing some of the simpler maintenance jobs on the reactor system.

During the period October 1, 1960 through March 11, 1961, the shield was utilized on nine jobs to a very definite advantage in the HRT maintenance program. A summary of these nine operations is listed in Table 1.

\section{LIMITATIONS OF THE SHIEID}

\section{Radiation Levels}

The shield was utilized to shield personnel from radiation levels of from $10 \mathrm{r} / \mathrm{hr}$. to over $200 \mathrm{r} / \mathrm{hr}$. Table 2 was compiled from actual radiation measurements and personnel exposure records during the performance of nine jobs.

Tools

The standard maintenance tools were used during this maintenance work. A special off-set lifting hook was built for use in replacing the blanket dump valve (PCV-252), allowing the job to be accomplished through the one lower plug opening.

Lead shot bags were used for shielding around tool handles. This proved to be adequate, but it would be more convenient to have split lead plugs to fit between the shield tool openings and the tool handles. There would also be an advantage in a standard tool handle diameter.

As tools were withdrawn from the shield, they were wiped down with a wet cloth. There was no significant contamination of the shield top during this maintenance work.

\section{Visibility}

Visibility was excellent through the shield as compared to working through water. The built-in lights proved quite adequate; however, for close viewing, a 500-w projector bulb on a drop cord was used to position the light source closer to the work area.

\footnotetext{
*P. P. Holz, Dry Maintenance Facility for the HRT, ORNL CF-60-10-85 (Oct. 11, 1960).
} 
Table 1. HRT Jobs Performed with the Ald of the Dry Maintenance Shleld

\begin{tabular}{|c|c|c|c|c|c|c|c|c|c|}
\hline & \multirow[b]{2}{*}{ Operation } & \multirow[b]{2}{*}{ Date } & \multicolumn{2}{|c|}{$\begin{array}{l}\text { Days After } \\
\text { Run Number }\end{array}$} & \multicolumn{2}{|c|}{ Radiation Level } & \multirow[b]{2}{*}{$\begin{array}{l}\text { Duration } \\
\text { of Job }\end{array}$} & \multirow{2}{*}{$\begin{array}{l}\text { Average } \\
\text { Daily } \\
\text { Radiation } \\
\text { Exposure } \\
\end{array}$} & \multirow[b]{2}{*}{ Comments } \\
\hline & & & Days & Run No. & $\begin{array}{l}\text { Lower Plug } \\
\text { Removed }\end{array}$ & $\begin{array}{l}\text { Shield } \\
\text { in Place }\end{array}$ & & & \\
\hline$(1)$ & Replace multiclone filter. & $10 / 17 / 60$ & 2 & 22 & $\begin{array}{l}10 \mathrm{r} / \mathrm{hr} \text { at } \\
\text { elev. } 830^{\circ}\end{array}$ & $\begin{array}{l}\text { Generel } \\
\text { beckground } \\
\text { of } 5 \mathrm{mr} / \mathrm{hr}\end{array}$ & $8 \mathrm{hr}$ & $30 \mathrm{mr}$ & $\begin{array}{l}\text { Job could not be done flooded because } \\
\text { there was no way to keep cell water } \\
\text { out of the reactor system. }\end{array}$ \\
\hline (2) & $\begin{array}{l}\text { Smear cell floor to locate } \\
\text { leak in high-pressure system. }\end{array}$ & $\begin{array}{l}12 / 6 / 60 \\
\text { and } \\
12 / 10 / 60\end{array}$ & 2 & 23 & $\begin{array}{l}120 \mathrm{r} / \mathrm{hr} \\
\text { at } \\
\text { elev. } 830^{\prime}\end{array}$ & $\begin{array}{l}\text { General } \\
\text { background } \\
\text { of } 20 \mathrm{mr} / \mathrm{hr}\end{array}$ & $120 \mathrm{hr}$ & $50 \mathrm{mr}$ & $\begin{array}{l}\text { Leak found at } \mathrm{E} \text {. head fuel feed pump. } \\
\text { This smear method of leak hunting } \\
\text { proved quite effective. The cell } \\
\text { could not be flooded. }\end{array}$ \\
\hline (3) & $\begin{array}{l}\text { Replace E. head fuel feed } \\
\text { pump. }\end{array}$ & $12 / 10 / 60$ & 6 & 23 & $\begin{array}{l}100 \mathrm{r} / \mathrm{hr} \\
\text { at } \\
\text { elev. } 830^{\prime}\end{array}$ & $\begin{array}{l}\text { General } \\
\text { background } \\
\text { of } 20 \mathrm{mr} / \mathrm{hr}\end{array}$ & $10 \mathrm{hr}$ & $1.5 \mathrm{r}$ & $\begin{array}{l}\text { The high personnel exposure was ac- } \\
\text { cumulated during the transfer of the } \\
\text { pump to the storage pool. The shield } \\
\text { was used to edvantage during the } \\
\text { actual replacement of the pump. }\end{array}$ \\
\hline$(4)$ & $\begin{array}{l}\text { Smear cell floor to locate } \\
\text { leak in reactor system. }\end{array}$ & $2 / 10 / 61$ & 2 & 24 & $\begin{array}{l}\text { From } \\
120 \mathrm{r} / \mathrm{hr} \\
\text { to } \\
\text { Over } \\
200 \mathrm{r} / \mathrm{hr}\end{array}$ & $\begin{array}{l}20 \mathrm{mr} / \mathrm{hr} \\
80 \mathrm{mr} / \mathrm{hr}\end{array}$ & $268 \mathrm{hr}$ & $70 \mathrm{mr}$ & $\begin{array}{l}\text { Leak found in line } 107 \text { at fuel dump } \\
\text { tanks. The cell could not be flooded } \\
\text { during this type of leak hunting. } \\
\text { Maintenance shield saved weeks of } \\
\text { shutdown time. Personnel exposures } \\
\text { were very low as a result of this } \\
\text { shield. }\end{array}$ \\
\hline (5) & $\begin{array}{l}\text { Install a clamp-on freezer } \\
\text { on ICV-145 fuel letdown } \\
\text { valve. }\end{array}$ & $2 / 17 / 61$ & 9 & 24 & $200 \mathrm{r} / \mathrm{hr}$ & $80 \mathrm{mr} / \mathrm{hr}$ & $10 \mathrm{hr}$ & $85 \mathrm{mr}$ & $\begin{array}{l}\text { Freezer installed to isolete the } \\
\text { reactor system from the fuel letdown } \\
\text { heat exchanger as part of the letdown } \\
\text { heat exchanger replacement. As a } \\
\text { result of these freezers the reactor } \\
\text { system was not contaminated with cell } \\
\text { water during this maintenance period. }\end{array}$ \\
\hline
\end{tabular}


Table 1. (continued)

\begin{tabular}{|c|c|c|c|c|c|c|c|c|c|}
\hline & \multirow[b]{2}{*}{ Operation } & \multirow[b]{2}{*}{ Date } & \multicolumn{2}{|c|}{$\begin{array}{l}\text { Days After } \\
\text { Run Number }\end{array}$} & \multicolumn{2}{|c|}{ Radiation Level } & \multicolumn{2}{|c|}{$\begin{array}{cc} & \text { Average } \\
\text { Daily } \\
\text { Duration Radiation }\end{array}$} & \multirow[b]{2}{*}{ Comments } \\
\hline & & & Deys & Run No. & $\begin{array}{c}\text { Lower Plue } \\
\text { Renioved }\end{array}$ & $\begin{array}{l}\text { Shield } \\
\text { in Place }\end{array}$ & $\begin{array}{l}\text { Duration } \\
\text { of Job }\end{array}$ & $\begin{array}{l}\text { Radiation } \\
\text { Exposure }\end{array}$ & \\
\hline (0) & $\begin{array}{l}\text { Install a clanp-on freezer on } \\
\text { Iine } 11 \text { at gas separator. }\end{array}$ & $2 / 28 / 61$ & 20 & 24 & $50 \mathrm{r} / \mathrm{hr}$ & $10 \mathrm{gr} / \mathrm{hr}$ & $12 \mathrm{hr}$ & $35 \pi r$ & $\begin{array}{l}\text { Freezer installed to isolate the } \\
\text { reactor system from the fuel letaown } \\
\text { heat exchanger as part of the letoown } \\
\text { heat exchanger replacenent. As a } \\
\text { result of these freezers, the reactor } \\
\text { system was not contaminated with cell } \\
\text { water during this maintenence period. }\end{array}$ \\
\hline$(7)$ & $\begin{array}{l}\text { Teplece PCV-25e blanket dump } \\
\text { valve. }\end{array}$ & $2 / 23 / 61$ & 15 & 24 & $10 \mathrm{r} / \mathrm{hr}$ & $15 \mathrm{mr} / \mathrm{hr}$ & $10 \mathrm{hr}$ & $20 \mathrm{mir}$ & $\begin{array}{l}\text { This was a difficult job due to the } \\
\text { location of the valve. It is doubt- } \\
\text { ful that the same job could have been } \\
\text { done if the radiation level had ex- } \\
\text { ceeded } 50 \mathrm{r} / \mathrm{hr} \text { with the roof plug } \\
\text { out. }\end{array}$ \\
\hline (8) & $\begin{array}{l}\text { Unbolt flanges } 111 \text {, } 112 \text {, and } \\
\text { liz at the fuel letdown heat } \\
\text { excinanger. Saw off heat ex- } \\
\text { change flanges and blank off } \\
\text { lines }\end{array}$ & $\begin{array}{l}2 / 24 / 61 \\
\text { and } \\
2 / 25 / 61\end{array}$ & 16 & 24 & $50 \mathrm{r} / \mathrm{hr}$ & $20 \mathrm{mr} / \mathrm{hr}$ & $32 \mathrm{hr}$ & $40 \mathrm{mr}$ & $\begin{array}{l}\text { Cell was flooded to elev, } 820 \text { and } \\
\text { flanges unbolted dry. The flanges were } \\
\text { blanked off, keeping cell water out } \\
\text { of the reactor system during the re- } \\
\text { moval of the fuel letdown heat ex- } \\
\text { changer. }\end{array}$ \\
\hline (y) & $\begin{array}{l}\text { Replace HCV- } 141 \text { and HCV-142 } \\
\text { chemical plant inlet and out- } \\
\text { let valves. }\end{array}$ & $\begin{array}{l}3 / 6 / 61 \\
\text { and } \\
3 / 11 / 61\end{array}$ & 26 & 24 & $10 r / \mathrm{hr}$ & $1.5 \mathrm{mr} / \mathrm{hr}$ & $144 \mathrm{hr}$ & $35 m$ & $\begin{array}{l}\text { On this job, the eccentric module was } \\
\text { used with the lead bridge. This } \\
\text { allowed the two lower plugs to be re- } \\
\text { moved. }\end{array}$ \\
\hline
\end{tabular}


Table 2. Radiation Limitations

\begin{tabular}{|c|c|c|c|c|}
\hline $\begin{array}{l}\text { Radiation* } \\
\text { Level With } \\
\text { Bottom Roof } \\
\text { Plug Removed }\end{array}$ & $\begin{array}{c}\text { Radiation } \\
\text { Level } \\
\text { Through } \\
\text { the 10.5" } \\
\text { Steel Shield }\end{array}$ & $\begin{array}{l}\text { General } \\
\text { Background } \\
36 " \text { Above } \\
\text { the Shield. } \\
\text { Avg. No. of } \\
\text { Tools Through } \\
\text { the Shield. }\end{array}$ & $\begin{array}{l}\text { Average } \\
\text { Working } \\
\text { Time for } \\
\text { a } 60 \text {-mr } \\
\text { Exposure }\end{array}$ & $\begin{array}{c}\text { Job } \\
\text { Limitations }\end{array}$ \\
\hline$(r / h r)$ & $(\mathrm{mr} / \mathrm{hr})$ & $(m r / h r)$ & $(h r)$ & \\
\hline 200 & 100 & 80 & 4 & $(1)$ \\
\hline 200 & 20 & 60 & 5 & (1) \\
\hline 120 & 15 & 30 & 9 & $(1),(2)$ \\
\hline 50 & -- & 10 & 16 & $(1),(2),(3)$ \\
\hline 10 & -- & 5 & 24 & $(1),(2),(3)$ \\
\hline
\end{tabular}

*Two to ten days after reactor shutdown.

NOTE: In all cases additional shielding of lead shot and brick was used to cover cracks in the shield. This accounts for the variations in radiation backgrounds and working times for a given radiation level.

(1) Tighten flanges, smear cell floor and observe equipment, etc., through the shield.

(2) Replace valves in a vertical position, replace feed pumps and purge pumps.

(3) Install clamp-on freezers, replace valves in horizontal position; limiting factor was the size of the opening through the shield. 
There is a need for larger viewing windows. Two 4-in.-diam. lead glass windows were used in existing tool holes. These viewing windows are too small to allow the tool operator to see through. It was necessary for a second man to observe and direct the operation. A 12-inch by 12-1nch lead glass viewing window mounted in the main slide as close to the eccentric module as possible would allow the tool operator to observe the work. An 8-power monocular was used to great advantage in viewing through the lead glass windows.

\section{Movement of Tools and Equipment}

The movement of tools and equipment is restricted as compared to underwater maintenance. This restriction did not prove to be great problem in any of the nine jobs. Tool flexibility could be increased if ball-joint-type tool shield plugs were used in place of the straight tool holes. This same flexibility was gained more crudely by utilizing a 4-inch hole for a l-1/2-inch tool handle and shielding with bags of lead shot.

The positioning of equipment in the cell was no problem. Off-set lifting hooks were built to further aid in the movement of equipment.

Mobility

The shield was set up over ten different work areas a total of twenty times. The first ten times required about $3-1 / 2$ hours per set up. This average set-up time was reduced to about 2 hours during the last ten times.

\section{CONCLUSIONS}

The use of the dry maintenance shield eliminated the need for flooding the reactor cell for shielding. This results in the following savings in reactor downtime:

1. One day to flood reactor cell.

2. Two days to drain reactor cell and dry out cell.

3. Two days to remove light water from the reactor system, on occasions when light water leaks past the freeze plugs.

4. It eliminates the need of disposing of $180,000 \mathrm{gal}$ of cell water that usually contains from 5 to 10 curies of activity.

The use of the dry maintenance shield increased personnel radiation exposures about $20 \%$ as compared to underwater maintenance.

This increase in personnel exposure can be eliminated with the following modifications to the shield:

1. Replace the tool holes with split ball shield plugs. This will provide the needed flexibility for tools and shielding around tool handles. 
2. Provide bolt-on-type lead shielding over the eccentric module gear drive and ring.

3. Install a 12-in. $x 12$-in. lead glass viewing window in the main shield as near as possible to the eccentric module. Install a 12-in. $x 12-i n$. lead glass vlewing window in one of the 2-ft 6-in. long modules.

The use of personal radiation monitors by personnel working through the shield will result in lower personnel exposures.

The time required to complete a specific job working through the dry maintenance shield was about the same as for underwater maintenance. The increase in visibility was an advantage that more than compensated for the restriction in tool and equipment movement. 


\author{
Distribution \\ 1-3. DTIE, AEC \\ 4. M. J. Sintmer
}


.

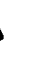

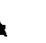

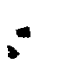

, 